\title{
Bupropion, Bayesian Logic and Serotonin Toxicity
}

\author{
P. Ken Gillman
}

Published online: 4 May 2010

(C) American College of Medical Toxicology 2010

Keywords Bupropion - Serotonin toxicity Bayesian logic

I suggest it is important to note that there are some powerful reasons for doubting the attribution of serotonin toxicity (ST) being caused by bupropion that is made in the report by Thorpe et al. [1]. It is well recognised that case reports are low-grade scientific evidence and can be misleading, to the extent of misdirecting doctors down blind alleys [2]. This can be especially counterproductive in emergency situations where less experienced physicians may not have time for protracted deliberation. I have emphasised previously that there is overwhelming evidence that potent serotonergic activity is an absolute prerequisite if a drug is to be capable of precipitating ST [3]. It may seem obvious to state that vitamin C cannot cause ST. A case report claiming that would be regarded sceptically because there is simply no basis for supposing that vitamin $\mathrm{C}$ is able to affect serotonin. That is Bayesian logic in operation, i.e., using the prior probability to weigh the expected outcome [4]. As I have pointed out before, drugs like bupropion and mirtazapine, that have no significant serotonergic activity, are no more likely to cause ST than is vitamin C [5]. This scenario has already been enacted, over a decade, with the antidepressant mirtazapine, which was claimed, erroneously, to have serotonergic activity. Many poor quality case reports of ST with mirtazapine were published. This probably led to misdirected treatment of overdoses, some of which may have caused morbidity. It took several reviews to correct this error and establish that mirtazapine cannot cause ST [6-8].

P. K. Gillman $(\bowtie)$

PsychoTropical Research,

P.O. Box 86, Bucasia, QLD 4750, Australia

e-mail: kg@matilda.net.au
These authors appear to be inviting us to repeat this time-wasting saga. There is no evidence that bupropion can increase 5-HT. Thorpe et al. carelessly and fallaciously represent Piacentini et al.'s results as reporting increased 5HT when, to the contrary, they clearly and specifically state that "5-HT showed no significant change after bupropion injection (Fig. 1C)." [9]. Bupropion has no potency as a serotonin re-uptake inhibitor [10]. There are large case series of overdoses and none of which have shown serotonergic toxicity, not even serotonergic side effects [11]. These would be expected if it had some other mysterious effect on 5-HT that is still unknown, which is unlikely after 30 years of use and research. One case report carries negligible weight when set in that context.

Despite the apparent presence of clonus, this case does not meet the Hunter serotonin toxicity criteria, specifically because no drug with established serotonergic activity was given. Bayesian logic indicates there is a low probability that this case represents ST. It is both fundamentally implausible and has other possible interpretations. It is a typical example of a report that is likely to mislead rather than illuminate, about which I have previously written [2].

Conflicts of interest None.

\section{References}

1. Thorpe EL, Pizon AF, Lynch MJ, Boyer J (2010) Bupropion induced serotonin syndrome: a case report. J Med Toxicol Mar 18 PMID:20238197. doi:10.1007/s13181-010-0021-x

2. Gillman PK (2006) Extracting value from case reports: lessons from serotonin toxicity. Anaesthesia 61:419-422 
3. Gillman PK (2006) A review of serotonin toxicity data: implications for the mechanisms of antidepressant drug action. Biol Psychiatry 59(11):1046-1051

4. Buckley NA, Whyte IM, Dawson AH (2002) Diagnostic data in clinical toxicology-should we use a Bayesian approach? J Toxicol Clin Toxicol 40(3):213-222

5. Gillman PK (2009) Triptans, serotonin agonists, and serotonin syndrome (serotonin toxicity): a review. Headache 50:264-272

6. Gillman PK (2006) A systematic review of the serotonergic effects of mirtazapine: implications for its dual action status. Hum Psychopharmacol 21:117-125

7. Millan MJ, Gobert A, Rivet JM, Adhumeau-Auclair A, Cussac D, Newman-Tancredi A et al (2000) Mirtazapine enhances frontocortical dopaminergic and corticolimbic adrenergic, but not serotonergic, transmission by blockade of alpha2-adrenergic and
serotonin2C receptors: a comparison with citalopram. Eur J Neurosci 12(3):1079-1095

8. Waring WS, Good AM, Bateman DN (2007) Lack of significant toxicity after mirtazapine overdose: a five-year review of cases admitted to a regional toxicology unit. Clin Toxicol (Phila) 45 (1):45-50

9. Piacentini MF, Clinckers R, Meeusen R, Sarre S, Ebinger G, Michotte Y (2003) Effect of bupropion on hippocampal neurotransmitters and on peripheral hormonal concentrations in the rat. J Appl Physiol 95(2):652-656

10. Tatsumi M, Groshan K, Blakely RD, Richelson E (1997) Pharmacological profile of antidepressants and related compounds at human monoamine transporters. Eur J Pharmacol 340(2-3):249-258

11. Balit CR, Lynch CN, Isbister GK (2003) Bupropion poisoning: a case series. Med J Aust 178(2):61-63 